\title{
MAGE-1 Gene m-RNA and VEGF in Blood as Potential Biochemical Markers for HCC in HCV Infected Patients
}

\author{
Yousri M.Hussein ${ }^{1}$; Yousri A. $E^{1}$; Wael H.E ${ }^{2}$; Osama A.E $E^{1}$; \\ Mohamed H. Mohamed Ali ${ }^{1}$ and Eman A.E ${ }^{1}$ \\ Medical Biochemistry ${ }^{1}$ and Oncology ${ }^{2}$ Depts. \\ Faculty of Medicine Zagazig University
}

\begin{abstract}
In the present study serum vascular endothelial growth factor (VEGF) and alphafetoprotein (AFP) and MAGE -1 m- RNA determination in blood by RT-PCR were assayed in seventy five individuals classified into five groups: control group (groupI) which comprised fifteen apparently healthy volunteers, group II which involved fifteen $\mathrm{HCV}$ infected patients without cirrhosis, group III involved fifteen HCV infected patients with cirrhosis, group IV included fifteen HCV infected patients with cirrhosis and early stage HCC and group V included fifteen HCV cirrhotic patients and late stage HCC. The results revealed that the frequency of positivity of MAGE-1 among the late hepatoma patients in group $V$ was $60 \%$, while in the early hepatoma patients in group IV the positivity was 13.3\%. The results for VEGF revealed a significant increase of serum VEGF in group V compared to control, II\& III groups and in group IV compared to group III. The obtained results of AFP, showed a significant positive increase of serum AFP in group $V$ when compared with group II and III and in group IV when compared with group II and III. In conclusion, detection of MAGE-1 transcripts in blood, especially with follow up survey, may help to predict the prognosis and monitoring of the response to the therapy, and the serum VEGF level in HCC patients is directly correlated with the metastasis and recurrence of tumors and increases gradually with the progression of HCC.
\end{abstract}

\section{INTRODUCTION}

Hepatocellular carcinoma (HCC) is the fifth most common tumor worldwide and the third cause of cancer-related deaths ${ }^{(1)}$. The estimated annual number of cases exceeds $500.000^{(2)}$. HCC occurs in more than $80 \%$ of cirrhotic liver, but the molecular pathways involved depend on the cause of the cirrhosis. Annual incidence of HCC in patients with cirrhosis due to hepatitis $\mathrm{B}$ virus (HBV) infection exceeds $2 \%$ and in those with cirrhosis due to hepatitis $C$ virus (HCV) infection, it is estimated between 3 and $8 \%{ }^{(3)}$. Association of the two viruses or chronic exposure to alcohol substantially increases these figures $^{(4)}$.

HCC represents more than 5\% of all cancer $^{(2)}$. In terms or relative frequencies, HCC ranks as the fifth most common cancer in the world, also, it is the eighth among women and it is the second among cancers of the digestive tract after stomach cancer $^{(5)}$. The most powerful risk 
factor for development of HCC is the existence of liver cirrhosis, regardless of its etiology ${ }^{(6)}$. Among cirrhotics, viral infection and high alcohol intake are associated with the highest risk ${ }^{(\mathbf{1})}$. Of the primary hepatitis viruses, only hepatitis $B$ and $C$ viruses cause $\mathrm{HCC}^{(6)}$.

Screening of each patient with cirrhosis of the liver regardless of etiology is of primordial importance for the detection of HCC in the initial stages of development ${ }^{(\mathbf{8})}$. Though regular sonographic examination and serum alpha-fetoprotein (AFP) can detect small HCC at an early stage and there are many modalities of treatment, the recurrence and metastasis are frequent and the prognosis remains unsatisfactory. The high recurrence rate is probably attributed to the dissemination of HCC cells into blood circulation. Early detection of metastatic tumor cells is critical to identify HCC patients at high risk of relapse and for the prescriptive therapy. However, it is difficult to detect such dissemination of HCC cells through blood route with conventional techniques $^{(\mathbf{9})}$. The RT-PCR has made it possible to detect molecular markers present at low copy numbers for the evaluation of micro-metastasis ${ }^{(9)}$. MAGE gene transcripts have been regarded as tumor-specific markers and found to be highly expressed in different types of cancers ${ }^{\mathbf{( 1 0 )}}$.

In 1991, researchers first isolated MAGE-A1 from an MZ-2 human melanoma cell line. In the following years, dozens of new MAGE gene were identified ${ }^{(\mathbf{1 1})}$. Based on expression patterns, the MAGEs were classified as belonging to either subgroup I or II. Members of subgroup I, including MAGE-A, -B and $-C$, are expressed in malignant tumors and testis, but not in other normal tissues. These members are named as cancer/testis antigen and tumor-specific antigen. In contrast, MAGEs subgroup II is expressed in various normal adult human tissues ${ }^{(\mathbf{1 2})}$. MAGE-1 is highly expressed in small HCC with a diameter of less than 2 $\mathrm{cm}$ and in well-differentiated HCC, so it is used for differentiating nonmalignant nodules from small and well-differentiated HCC. Also, It was found expressed in AFP-negative and can be useful as a tumor-specific marker for the detection of circulating HCC cells in peripheral blood ${ }^{(\mathbf{1 3 )}}$.

Moreover, tumor growth relies on angiogenesis, the formation of new blood vessels from pre-existing vascular beds, in order to receive an adequate supply of oxygen and nutrients ${ }^{(\mathbf{1 4})}$. Genetic changes and local hypoxia in tumors lead to secretion of soluble angiogenic factors, which activate a complex interplay between different cells, the basal membrane and soluble pro- and antiangiogenic factors ${ }^{(4)}$.

Vascular endothelial growth factor (VEGF) is the best investigated angiogenic factor in HCC. Tumor expression of VEGF (m-RNA and protein expression) significantly correlates with serum VEGF level in patients with HCC providing the basis for using circulating VEGF as a prognostic marker ${ }^{(3)}$.

So, the present study was designed to evaluate the expression of MAGE-1 m-RNA and the levels of VEGF and AFP in peripheral blood as potential biochemical markers for 
diagnosis and prognosis of $\mathrm{HCV}$ infection complications like cirrhosis and HCC.

\section{SUBJECTS \& METHODS}

Six ml of venous blood were drawn from 75 individuals; 15 healthy controls, 15 HCV infected patients without any complications (cirrhosis, or HCC) 15 HCV infected patients complicated with cirrhosis, $15 \mathrm{HCV}$ infected patients complicated with cirrhosis and localized HCC and 15 HCV patients complicated with cirrhosis and metastatic HCC. Three $\mathrm{ml}$ of blood was collected in heparinized tube for separation of peripheral blood mononuclear cells (PBMCs) for determination of MAGE-1 m-RNA. The other $3 \mathrm{ml}$ of blood were used for separation of serum to detect AFP and VEGF.

PBMCs were separated using Lymphoflot containing sodium diatrizoate and Ficoll, supplied by (Biotest, Dreieich, Germany) which is ready-to-use and sterile filtered density gradient for the isolation of lymphocytes.

RT円PCR: Total RNA was extracted from isolated PBMCs using E.Z.N.A. total RNA kit (supplied by Omega Biotek, USA) according to the protocol provided by the manufacturer.

Reverse transcription and PCR amplification were performed using Ready-to-Go RT-PCR Beads kit (No: 27-9266-01), supplied by Amersham Biosciences limited, Amersham Place, Little Chalfont, Buckinghamshire, HP7 9NA, UK. Each bead is optimized to allow first-strand cDNA synthesis and PCR reactions to proceed as a single tube; when brought to a final volume of $50 \mu \mathrm{l}$, each reaction contained $\sim 2$ units of taq DNA polymerase, $10 \mathrm{mM}$ Tris-HCl, $60 \mathrm{mM} \mathrm{KCl}, 1.5 \mathrm{mM} \mathrm{MgCl} 2,200 \mu \mathrm{M}$ of each dNTP, M-MULV Reverse Transcriptase, RNA guard Ribonuclease inhibitor (porcine) and stabilizers including RNase/DNase free bovine serum albumin (BSA).

The bead was dissolved using DEPC-dd $\mathrm{H}_{2} \mathrm{O}$, then 2.5 $\mu \mathrm{g}$ RNA template and $3 \mu \mathrm{l}$ of the first strand (cDNA) primer $\operatorname{pd}\left(\mathrm{N}_{6}\right)$ were added individually to the dissolved bead, the reactions were transferred to the thermal cycler and incubated at $42{ }^{\circ} \mathrm{C}$ for 30 minutes, then at $95{ }^{\circ} \mathrm{C}$ for 5 minutes, then $2.5 \mu \mathrm{l}$ of each PCR primer was added (The sequences of MAGE-1 primers and length of PCR products were as follows: forward-5'CGG CCG AAG GAA CCT GAC CCA G-3' and reverse-5'-GCT GGA ACC CTC ACT GGG TTG CC-3', size, 421 base pair $\left.(\mathrm{bp})^{(\mathbf{9})}\right)$. The volume of the reaction was completed with DEPC-dd $\mathrm{H}_{2} \mathrm{O}$ to give a final volume of $50 \mu \mathrm{l}$ where it was used for dissolving the bead.

The PCR amplifications were performed by pre-programmed Thermal Cycler PTC-100 machine (MJ Research, Inc., Watertown, Mass. USA) under the following conditions according to ${ }^{(9)}$ : $\left(94^{\circ} \mathrm{C}\right.$ for $45 \mathrm{~s}, 65^{\circ} \mathrm{C}$ for $45 \mathrm{~s}$ and $72^{\circ} \mathrm{C}$ for $45 \mathrm{~s}$ ) for 25 cycles.

B-actin gene was determined to assess the integrity of the RNA. The sequences of B-actin primers and length of PCR products were as follows: forward-5'-GGC ATC GTG ATG GAC TCC G-3' and reverse-5'GCT GGA AGG TGG ACA GCG A- 
3', size, $613 \mathrm{bp}$. The amplification was $94^{\circ} \mathrm{C}$ for $45 \mathrm{~s}, 65^{\circ} \mathrm{C}$ for $45 \mathrm{~s}$ and $72^{\circ} \mathrm{C}$ for $45 \mathrm{~s}$ for 28 cycles $^{(\mathbf{9})}$.

The amplified products were run in $1.7 \%$ agarose gel using the EC 360 Submarine Gel electrophoresis system (Maxicell, EC 360 M-E-C apparatus Cooperation St. Petersburg. Florida (USA). The results were visualized by ethidium bromide staining under ultraviolet transillumination, then digital camera photographing.

The sample was considered positive when a band was observed at 421 bp for MAGE-1 and also B-actin gene was determined to assess the integrity of the RNA where it gave a band at $613 \mathrm{bp}$, using a DNA marker (100 bp+1.5 kb DNA).

Determination of serum VEGF: Serum VEGF was determined by ELISA technique, using kit (No: 5.587.294), supplied by Cytimmune Sciences, Inc., College Park, Maryland.

Determination of serum AFP: AFP was determined by ECLIA technique that is intended for use on the Roche Elecsys 2010 immunoassay analyzer using AFP reagent kit (No: 11731327), supplied by Roche diagnostics Gmbh, D-68298 Mannheim.

\section{RESULTS}

MAGE-1 m-RNA was not detected in PBMCs from the 15 healthy donors (group I, the control), and, also, in groups II (HCV without cirrhosis) and group III (HCV complicated with cirrhosis). In group IV (localized HCC), the positive rate of MAGE-1 transcript in PBMCs was $13.3 \%$ (2 out of 15 ), whereas in group $\mathrm{V}$ (metastatic HCC), it was detected in $60 \%$ (9 out of 15). The positive results of MAGE-1 in all HCC patients were $36.7 \%$.

The distribution of MAGE-1 expression among healthy volunteers, hepatitis and cirrhosis patients and HCC patients indicates that MAGE-1 m-RNA is cancer-specific, and could be detected in samples from patients with HCC (specificity=100\%).

By using Fisher`s exact test, the frequency of the MAGE-1 transcript detected in PBMCs was significantly higher in metastatic HCC group than localized HCC one $(\mathrm{P}=0.021)$. Also, high significant frequency of MAGE1 m-RNA was detected in group $\mathrm{V}$ than group I, II, III $(\mathrm{P}<0.05)$. No significant difference of MAGE-1 expression was detected between groups IV and group I, II, and III (P> $0.05)$.

Incidence of MAGE-1 m-RNA among different groups.

Incidence of MAGE-1 m-RNA among different groups.

\begin{tabular}{|c|c|c|c|c|c|c|c|c|}
\hline & \multicolumn{5}{|l|}{ Group } & \multirow{2}{*}{$\frac{\text { Specificity }}{100 \%}$} \\
\hline & & & $\mathrm{I}$ & II & III & IV & $\mathrm{V}$ & \\
\hline \multirow[t]{4}{*}{ MAGE-1 } & \multirow[t]{2}{*}{-ve } & Count & 15 & 15 & 15 & 13 & 6 & \\
\hline & & $\%$ & $100 \%$ & $100 \%$ & $100 \%$ & $86.7 \%$ & $40 \%$ & \\
\hline & \multirow[t]{2}{*}{$+\mathrm{ve}$} & Count & 0 & 0 & 0 & 2 & 9 & \\
\hline & & $\%$ & $0 \%$ & $0 \%$ & $0 \%$ & $13.3 \%$ & $60 \%$ & \\
\hline
\end{tabular}


Fisher`s exact test for MAGE-1 m-RNA in all studied groups.

Fisher`s exact test for MAGE-1 m-RNA in all studied groups.

\begin{tabular}{|l|l|l|l|l|}
\hline \multirow{2}{*}{ Group } & I & II & III & IV \\
\cline { 2 - 5 } & P & P & P & P \\
\hline V & $<0.001$ & $<0.001$ & $<0.001$ & $<0.05$ \\
\hline IV & $>0.05$ & $>0.05$ & $>0.05$ & \\
\hline
\end{tabular}

(A) B-actin

Electrophoresis of PCR products of gene transcripts of PBMCs samples from localized HCC patients

Electrophoresis of PCR products of gene transcripts in PBMCs samples from metastatic HCC patients
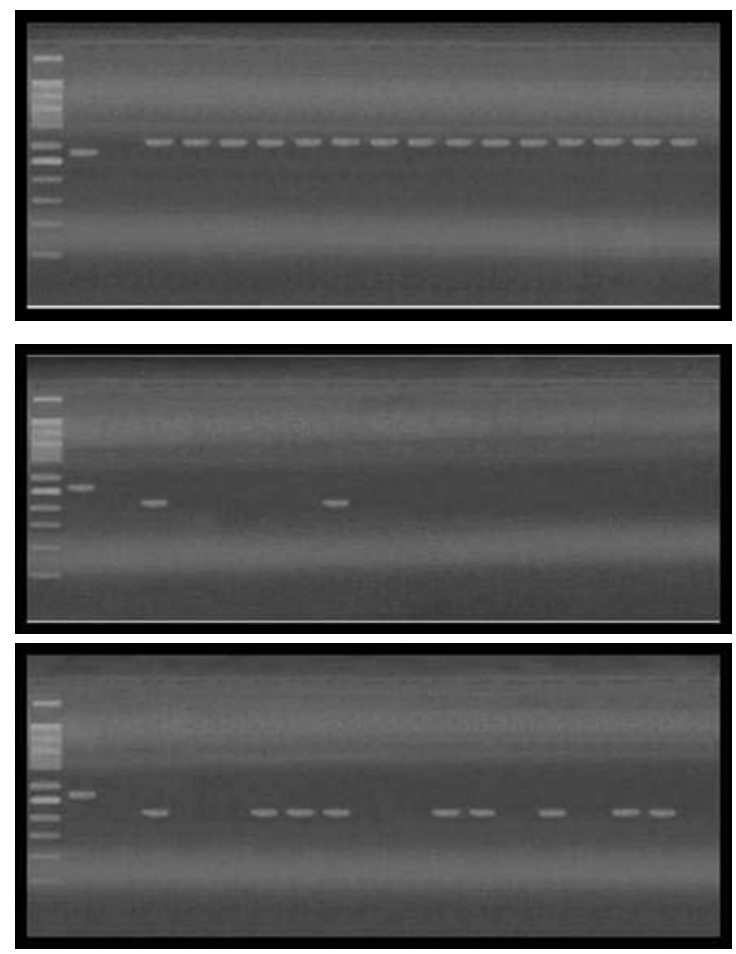

Serum VEGF: Statistical analysis and results of serum VEGF ( $\mathrm{ng} / \mathrm{ml})$ in different investigated groups; In control group (group I), serum VEGF ranged from 0.244 to $14.53 \mathrm{ng} / \mathrm{ml}$, with a mean value \pm SD of $7.3 \pm 4.77$ $\mathrm{ng} / \mathrm{ml}$ and the median was $7.24 \mathrm{ng} / \mathrm{ml}$. In group II, serum VEGF varied from 3.12 to $26.73 \mathrm{ng} / \mathrm{ml}$, with a mean value \pm SD of $10.5 \pm 6.77 \mathrm{ng} / \mathrm{ml}$ and the median was $7.86 \mathrm{ng} / \mathrm{ml}$. As regard group III, serum VEGF ranged from
0.23 to $10 \mathrm{ng} / \mathrm{ml}$, with a mean value \pm $\mathrm{SD}$ of $5.04 \pm 2.87 \mathrm{ng} / \mathrm{ml}$ and the median was $4.38 \mathrm{ng} / \mathrm{ml}$. In group IV, serum VEGF ranged from 5.5 to 27.27 $\mathrm{ng} / \mathrm{ml}$, with a mean value \pm SD of 17 $\pm 6.55 \mathrm{ng} / \mathrm{ml}$ and the median was 19.7 $\mathrm{ng} / \mathrm{ml}$. In group $\mathrm{V}$, serum VEGF ranged from 18.89 to $118.68 \mathrm{ng} / \mathrm{ml}$, with a mean value \pm SD of $47.75 \pm$ $27.82 \mathrm{ng} / \mathrm{ml}$ and the median was 40.4 $\mathrm{ng} / \mathrm{ml}$. 
By using simple analysis of variance, a significant difference of the mean values of serum VEGF was found between various studied groups ( $F=25.672, \mathrm{P}<0.001)$. Also, by using LSD test; a significant increase of serum VEGF was detected in group $\mathrm{V}$ $(\mathrm{P}<0.001)$ while there were non significant differences in other patient groups $(\mathrm{P}>0.05)$ when groups were compared with control group (group
I). When patient groups were compared with each other, a significant increase was detected in group $\mathrm{V}$ as compared with group II, III, IV ( $\mathrm{P}<0.001)$. Also, a significant increase was detected in group IV as compared with group III $(\mathrm{P}<0.05)$. Non significant differences were detected between group IV and II and between group III and II.

Descriptive statistics of serum VEGF among different groups.

\begin{tabular}{|l|l|l|l|l|l|l|}
\hline Group & N & Minimum & Maximum & Median & Mean & S.D \\
\hline I & 15 & 0.244 & 14.53 & 7.24 & 7.3 & 4.77 \\
\hline II & 15 & 3.12 & 26.73 & 7.86 & 10.5 & 6.77 \\
\hline III & 15 & 0.23 & 10 & 4.38 & 5.04 & 2.87 \\
\hline IV & 15 & 5.5 & 27.27 & 19.7 & 17 & 6.55 \\
\hline V & 15 & 18.89 & 118.68 & 40.4 & 47.75 & 27.82 \\
\hline
\end{tabular}

$\mathrm{F}=25.672, \quad \mathrm{P}<0.001$

\section{LSD for VEGF in all studied groups.}

\begin{tabular}{|l|l|l|l|l|}
\hline \multirow{2}{*}{ Group } & Group I & Group II & Group III & Group IV \\
\cline { 2 - 5 } & $\mathrm{P}$ & $\mathrm{P}$ & $\mathrm{P}$ & $\mathrm{P}$ \\
\hline V & $<0.001$ & $<0.001$ & $<0.001$ & $<0.001$ \\
\hline IV & $>0.05$ & $>0.05$ & $<0.05$ & \\
\hline III & $>0.05$ & $>0.05$ & & \\
\hline II & $>0.05$ & & & \\
\hline
\end{tabular}

Serum VEGF (ng/ml) in all studied groups.

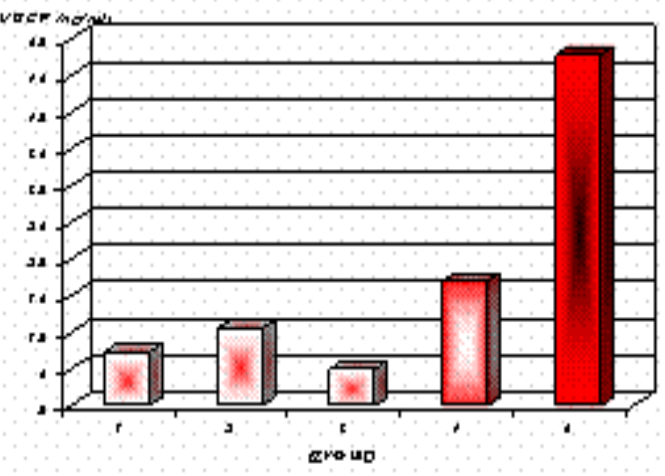


Different ranges; 0-20; the normal range suggested by Kreczko et al., ${ }^{(15)}$, 20-100, 100-1000 and > $1000 \mathrm{ng} / \mathrm{ml}$. All control subjects had AFP levels within the normal ranges $(0-20$ $\mathrm{ng} / \mathrm{ml})$. Patients with hepatitis varied in their AFP distribution, where 11 patients had AFP values $0-20 \mathrm{ng} / \mathrm{ml}$ and 4 patients had values from $20-100$ $\mathrm{ng} / \mathrm{ml}$. In cirrhotics, 12 patients had AFP values $0-20 \mathrm{ng} / \mathrm{ml}$, whereas 3 patients had levels from $20-100 \mathrm{ng} / \mathrm{ml}$. In patients with localized HCC, two patients were found having AFP levels $0-20 \mathrm{ng} / \mathrm{ml}$ and 6 patients had AFP values $20-100 \mathrm{ng} / \mathrm{ml}$ while 7 patient had AFP levels 100-1000 $\mathrm{ng} / \mathrm{ml}$, whereas in patients with metastatic HCC, only one patient was found having AFP $0-20 \mathrm{ng} / \mathrm{ml}, 5$ patients had AFP levels $20-100 \mathrm{ng} / \mathrm{ml}$, 5 patients had AFP $100-1000 \mathrm{ng} / \mathrm{ml}$ and 4 patients more than $1000 \mathrm{ng} / \mathrm{ml}$.

Statistical analysis and results of serum AFP (ng/ml) in different investigated groups:

In control group (group I) serum AFP ranged from 1.5 to $5.3 \mathrm{ng} / \mathrm{ml}$, with a mean value \pm SD of $3.2 \pm 1.2$ $\mathrm{ng} / \mathrm{ml}$ and the median was $3 \mathrm{ng} / \mathrm{ml}$. In group II, serum AFP varied between 3.3 to $36.8 \mathrm{ng} / \mathrm{ml}$, with a mean value $\pm \mathrm{SD}$ of $13.1 \pm 10.4 \mathrm{ng} / \mathrm{ml}$ and the median was $7 \mathrm{ng} / \mathrm{ml}$. As regard group
III, serum AFP ranged from 4.8 to 40 $\mathrm{ng} / \mathrm{ml}$, with a mean value $\pm \mathrm{SD}$ of $14.98 \pm 10.6 \mathrm{ng} / \mathrm{ml}$ and the median was $13.5 \mathrm{ng} / \mathrm{ml}$. In group IV, serum AFP ranged from 14 to $415 \mathrm{ng} / \mathrm{ml}$, with a mean value \pm SD of $135.6 \pm$ $131.7 \mathrm{ng} / \mathrm{ml}$ and the median was 92 $\mathrm{ng} / \mathrm{ml}$. In group V, serum AFP ranged from 20 to $6050 \mathrm{ng} / \mathrm{ml}$, with a mean value \pm SD of $1086 \pm 2044.4 \mathrm{ng} / \mathrm{ml}$ and the median was $175 \mathrm{ng} / \mathrm{ml}$. By using Kruskal Wallis test, a significant difference of the mean values of serum AFP was found between various studied groups $(\mathrm{H}=58.5, \mathrm{P}<$ 0.001). Also, by using Mann-Whitney test; a significant positive increase of serum AFP was detected in all patient groups when compared with control group (group I) $(\mathrm{P}<0.001)$. When patient groups were compared with each other, a significant positive increase of serum AFP was detected in group $\mathrm{V}$ when compared with group II and III $(\mathrm{P}<0.001)$, whereas a non significant increase was detected in group $\mathrm{V}$ when compared with group IV $(\mathrm{P}>0.05)$. A significant increase was observed in group IV when compared with group II and III $(\mathrm{P}<0.001)$. A non significant increase was detected in group III as compared with group II $(\mathrm{P}>0.05)$.

Different concentration ranges of AFP in the four patient groups and controls.

\begin{tabular}{|l|l|l|l|l|}
\hline \multirow{2}{*}{ Patient groups } & \multicolumn{4}{|l|}{ AFP concentration range (ng/ ml) } \\
\cline { 2 - 5 } & $\mathbf{0 - 2 0}$ & $\mathbf{2 0 - 1 0 0}$ & $\mathbf{1 0 0 - 1 0 0 0}$ & $>\mathbf{1 0 0 0}$ \\
\hline V & 1 & 5 & 5 & 4 \\
\hline $1 \mathrm{~V}$ & 2 & 6 & 7 & 0 \\
\hline III & 12 & 3 & 0 & 0 \\
\hline II & 11 & 4 & 0 & 0 \\
\hline Control (I) & 15 & 0 & 0 & 0 \\
\hline
\end{tabular}


Descriptive statistics of serum AFP (ng/ml) in all studied groups:

\begin{tabular}{|l|l|l|l|l|l|l|}
\hline Group & $\mathbf{N}$ & Minimum & Maximum & Median & Mean & S.D \\
\hline I & 15 & 1.5 & 5.3 & 3 & 3.2 & 1.2 \\
\hline II & 15 & 3.3 & 36.8 & 7 & 13.1 & 10.4 \\
\hline III & 15 & 4.8 & 40 & 13.5 & 14.98 & 10.6 \\
\hline IV & 15 & 14 & 415 & 92 & 135.6 & 131.7 \\
\hline V & 15 & 20 & 6050 & 175 & 1086 & 2044.4 \\
\hline
\end{tabular}

Kruskal Wallis test:H= 58.5

$\mathbf{P}<\mathbf{0 . 0 0 1}$

Mann-Whitney test (U) for AFP.

\begin{tabular}{|l|l|l|l|l|}
\hline Group & Group I & Group II & Group III & Group IV \\
\hline & P & P & P & P \\
\hline V & $<0.001$ & $<0.001$ & $<0.001$ & $>0.05$ \\
\hline IV & $<0.001$ & $<0.001$ & $<0.001$ & \\
\hline III & $<0.001$ & $>0.05$ & & \\
\hline II & $<0.001$ & & & \\
\hline
\end{tabular}

Distribution of AFP in all studied groups.
Median AFP level $\mathrm{ng} / \mathrm{ml}$ in all studied groups
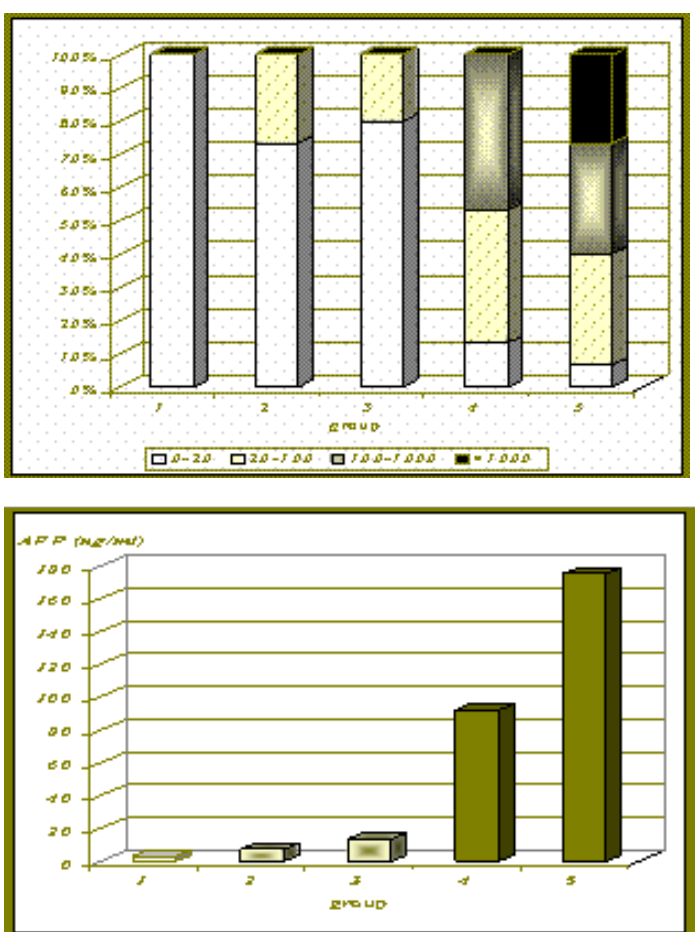
Correlation Coefficient: By using Spearman correlation between MAGE-1 m-RNA and VEGF and between MAGE-1 m-RNA and AFP and also by using Pearson correlation between VEGF and AFP the following results were obtained: Positive correlation between VEGF and AFP in all studied individuals ( $\mathrm{r}=$ $0.34, \mathrm{P}<0.01)$ and in group II $(\mathrm{r}=0.76$, $\mathrm{P}<0.01$ ) whereas, non significant correlations in groups I and III, but in hepatoma groups, non significant correlations were detected between all studied parameters in localized or metastatic HCC groups.

Correlation between VEGF and AFP in group I, II, III.

\begin{tabular}{|l|l|l|l|}
\hline & $\mathrm{n}$ & $\mathrm{r}$ & $\mathrm{P}$ \\
\hline All groups & 75 & 0.34 & $<0.01$ \\
\hline Group I & 15 & 0.44 & $>0.05$ \\
\hline Group II & 15 & 0.76 & $<0.01$ \\
\hline Group III & 15 & -0.16 & $>0.05$ \\
\hline
\end{tabular}

Correlation of different studied parameters in group IV. $(n=15)$

\begin{tabular}{|c|c|c|c|c|}
\hline & \multicolumn{2}{|c|}{ MAGE-1 m-RNA } & \multicolumn{2}{|c|}{ VEGF } \\
\hline & $\mathrm{r}$ & $\mathrm{P}$ & $r$ & $\mathrm{P}$ \\
\hline VEGF & 0.00 & $>0.05$ & & \\
\hline AFP & 0.14 & $>0.05$ & 0.2 & $>0.05$ \\
\hline
\end{tabular}

Correlation of different studied parameters in group V. $(n=15)$

\begin{tabular}{|c|c|c|c|c|}
\hline & MAG & & VEG & \\
\hline & $r$ & $\mathrm{P}$ & $r$ & $\mathbf{P}$ \\
\hline VEGF & 0.38 & $>0.05$ & & \\
\hline AFP & 0.22 & $>0.05$ & 0.03 & $>0.05$ \\
\hline
\end{tabular}

Correlation Coefficient between serum VEGF and AFP in all studied individuals.

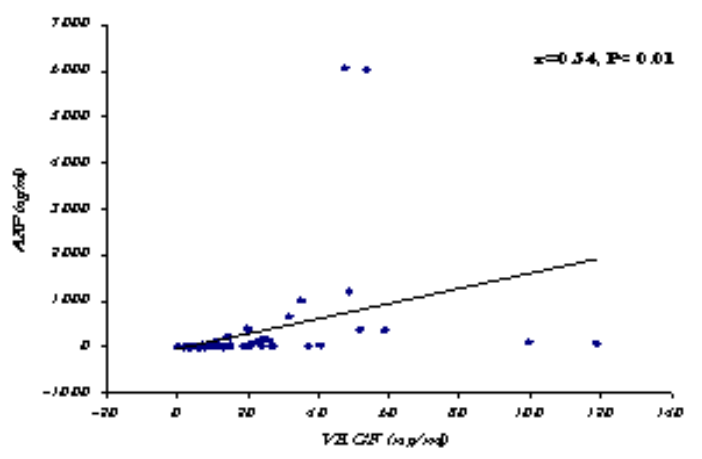




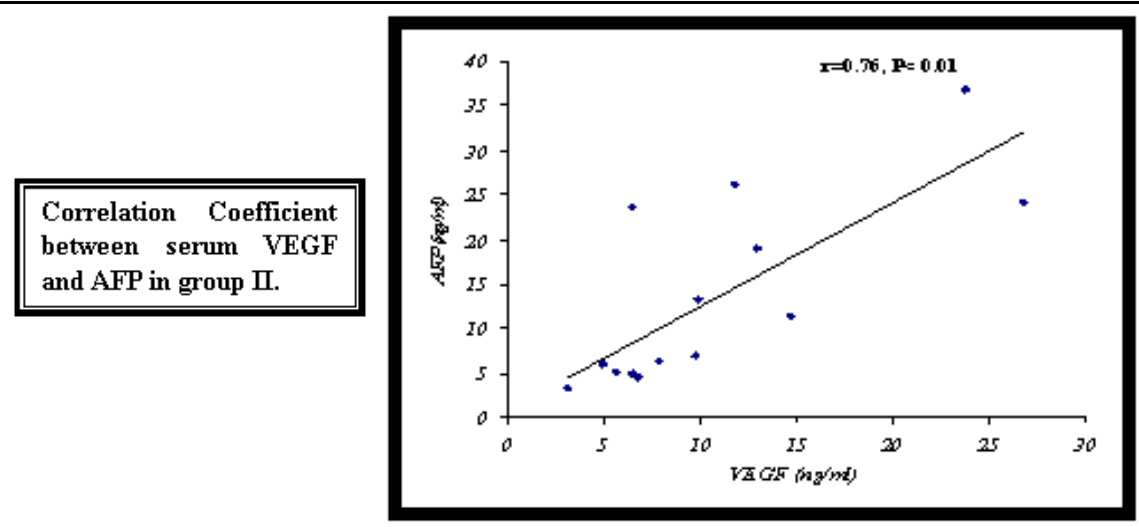

\section{DISCUSSION}

The RT-PCR has made it possible to detect molecular markers present at low copy numbers for the evaluation of micro-metastasis ${ }^{(\mathbf{9})}$. Both albumin and AFP m-RNA are widely used as tumor markers for HCC cells in circulation $^{(\mathbf{1 6})}$. However, the reliability using them as tumor markers has been challenged, because both albumin and AFP are abundantly expressed in normal liver cells and released to the peripheral blood by either surgical injury of the liver for diseases other than HCC or by hepatitis virus infection $^{(\mathbf{9})}$. It is, therefore, necessary to screen tumor-specific markers, which are specifically and frequently expressed in HCC.

MAGE-1 gene transcript has been found to be highly expressed in different histological types of cancers. In the case of HCC, the positive rate was $46-80 \%$ in HCC tissue samples while no expression was detected in the surrounding non-cancerous tissues or cirrhotic, $\mathrm{HBV} / \mathrm{HCV}$ infection or normal ones ${ }^{(\mathbf{1 0})}$. Moreover, tumor growth relies on angiogenesis ${ }^{\mathbf{( 1 4 )}}$. Genetic changes and local hypoxia in tumors lead to secretion of soluble angiogenic factors, which activate a complex interplay between different cells, the basal membrane and soluble pro- and antiangiogenic factors ${ }^{(4)}$.

Vascular endothelial growth factor (VEGF) is the best investigated angiogenic factor in HCC. Tumor expression of VEGF (m-RNA and protein expression) significantly correlates with serum VEGF level in patients with HCC providing the basis for using circulating VEGF as a prognostic marker ${ }^{(7)}$.

So, the current study was designed to evaluate the expression of MAGE-1 m-RNA and the levels of VEGF and AFP in peripheral blood as potential biochemical markers for diagnosis and prognosis of HCV infection complications like cirrhosis and HCC.

Determination of MAGE-1 mRNA in PBMCs by RT-PCR assay revealed that, $36.7 \%$ (11 out of 30 HCC) patients were found to be positive for MAGE-1 m-RNA. Detection of MAGE-1 transcript in PBMCs is closely correlated to the pathological stages of HCC. The more advanced stages of HCC, the higher 
rate of micro-metastasis of cancer cells detectable in peripheral blood and the higher frequency of positivity of MAGE-1 transcript among group V (metastatic HCC) (60\%, 9 out of 15), while in group IV (localized HCC), the positivity was $13.3 \%$, (2 out of 15) (with significant increase in group $\mathrm{V}$ than group IV; $\mathrm{P}<0.05$ ). All samples from healthy volunteers and patients with hepatitis and cirrhosis were negative. These results indicate that MAGE-1 m-RNA is cancerspecific and could be detected in samples from patients with HCC (specificity $=100 \%$ ).

According to the TNM criteria, the HCC in early stages should have no metastasis of tumor cells except the possibly intrahepatic metastasis. The assay by RT-PCR to detect MAGE-1 transcript; the tumor-specific marker, revealed that, $13.3 \%$ patients with HCC in group IV already had micrometastasis to the peripheral blood, so MAGE-1 transcript can detect occult hematogenous dissemination of HCC cells much earlier than any other means. This parameter firmly indicates that blood dissemination of tumor cells has already occurred in the early stages of HCC. It is probably the reason why some patients still suffer recurrence after the radical resection of the tumor. These results coïncide with those previously reported by Kobayashi et al. ${ }^{(15)}$; Peng et al. ${ }^{(18)}$; Mou et al. ${ }^{(9)}$; Yang et al. ${ }^{(19)}$ and Yang et al. ${ }^{(10)}$.

As regard the obtained results of serum VEGF, a significant increase was detected in localized HCC group as compared with cirrhosis group $(\mathrm{P}<$ 0.05). Also, a significant increase was detected in metastatic HCC group as compared with localized HCC, cirrhosis, hepatitis and healthy control groups $\quad(\mathrm{P}<0.001)$. No other significant differences were detected between the studied groups. These results are comparable with those of Li et al. ${ }^{(21)}$; Poon et al. ${ }^{(22)}$; Li et al. ${ }^{(23)}$, Schmitt et al. ${ }^{(24)}$ and Yao et al. ${ }^{(25)}$.

Concerning the obtained results of serum AFP, when localized and metastatic HCC groups were compared with cirrhosis, hepatitis and healthy controls ones, a significant increase was observed ( $\mathrm{P}<0.001)$, whereas a non significant difference was observed when they were compared with each other $(\mathrm{P}>0.05)$. Also, a non significant difference was detected between cirrhosis and hepatitis groups $(\mathrm{P}>0.05)$ but when they were compared with healthy control one, a significant increase of serum AFP was detected $(\mathrm{P}<$ 0.001).The current results agree with those of Kreczko et al. ${ }^{(15)} ; \mathrm{Mou}$ et al. ${ }^{(9)}$; Peng et al. ${ }^{(26)}$; Ali et al. ${ }^{(27)}$; He et al. ${ }^{(28)}$ and Di Bisceglie et al. ${ }^{(29)}$.

The present results concerning the correlation between the serum levels of AFP and tumor metastasis conflict with Peng et al. ${ }^{(26)}$ who reported that, high AFP level correlates with high stage, early recurrence and poor prognosis of HCC. Also, the significant increase of serum AFP in hepatitis $C$ group than control one disagrees with that of $\mathbf{A l i}$ et al. ${ }^{(27)}$ who found non significant difference in AFP levels between chronic hepatitis $\mathrm{C}$ and healthy control.

The conflicting findings between the results of the current study and the others may be explained by $\boldsymbol{D i}$ Bisceglie et al. ${ }^{(29)}$ who postulated that, 
AFP levels are affected by the severity of chronic hepatitis C. Also, Chu et al. $^{(30)}$ reported that, elevated serum AFP levels are significantly correlated with advanced fibrosis/cirrhosis.

Though elevation of serum AFP has been routinely applied as a parameter for HCC diagnosis, Jiang et al. ${ }^{\text {(31) }}$ reported that, AFP transcripts were detected in normal liver cells, the liver cirrhosis and the liver infectious diseases such as $\mathrm{HBV} / \mathrm{HCV}$ infection. Furthermore, Malek et al. (17) stated that, AFP transcripts were detected even in the blood samples from patients without HCC after the surgical injury of the liver, which results in the shedding of liver cells into circulation under surgical operation. Thus, AFP may represent a liver cell-specific marker, not a tumorspecific marker.

Though Mou et al. ${ }^{(9)}$ postulated that, in HCC, the majority of HCC cells produce AFP leading to its elevation in blood samples and providing a diagnostic marker. In the present study it was found that, $26.7 \%$ (4 out of 15 patients of group IV) with serum AFP levels being lower than $40 \mathrm{ng} / \mathrm{ml}$ (the cut off value suggested by $\mathbf{M o u}$ et $\boldsymbol{a l}^{\left({ }^{(9)}\right.}$ to diagnose HCC patients). Also, the present study showed that, the elevation of AFP is not correlated with the progression of the HCC.

For the previous reasons, it could be suggested to use AFP as a supplementary marker to help diagnosis of HCC, but not to detect circulating HCC cells. Moreover, Zhou et al. ${ }^{(32)}$ reported that, AFP exists in three isoforms, namely AFPL1, AFP-L2 and AFP-L3, based on their different affinities to lectin,
(LCA). AFP-L1 is the major glycoform of AFP in the serum of nonmalignant hepatopathy patients. On the contrary, AFP-L3 is the major glycoform of AFP in the serum of HCC patients. Measurement of total AFP and AFP-L3 may provide more clinically useful information than total AFP alone. AFP-L3 appears to be produced only by cancer cells. Detection of AFP-L3 is more sensitive method to diagnose HCC in patients with chronic HCV and HBV infection. Furthermore, the high percentage of AFP-L3 is closely related to poor differentiation and biologically malignant characteristics (especially portal vein invasion) of HCC, and HCC patients with positive AFP-L3 would have worse liver function, poorer tumor histology and larger tumor mass.

Regarding the correlation matrix, a positive correlation between VEGF and AFP in all studied individuals $(\mathrm{r}=0.34, \quad \mathrm{P}<0.01)$ and in hepatitis group ( $\mathrm{r}=0.76, \mathrm{P}<0.01$ ) were obtained, whereas non significant correlations were detected in healthy control and cirrhosis groups. In hepatoma groups, non significant correlations were detected between all studied parameters in localized or metastatic HCC groups.

With respect to the non significant correlation between the expression of MAGE-1 m-RNA and AFP, it was explained by Yang et al. $^{\text {(20) }}$ who stated that, the level of serum AFP in patients with HCC is not necessarily consistent with the expression of MAGE-1 m-RNA. The level of secreted serum AFP protein may be not proportional with the presence of MAGE-1 m-RNA 
producing HCC cells in the circulatory system. Also, it may be the explanation of the non significant correlation between MAGE-1 and VEGF where Poon et al. ${ }^{(3)}$ reported that, tumor expression of VEGF (mRNA and protein expression) significantly correlates with serum VEGF level in patients with HCC.

In conclusion, detection of MAGE-1 m-RNA in blood and serum VEGF and AFP levels has different significances. As regard MAGE-1 mRNA, it seems to be a parameter to detect occult hematogenous dissemination of HCC cells much earlier than any other means. So, detection of MAGE-1 transcript in blood, especially with follow up, may help to prefigure HCC metastasis and monitor the response to the therapy. Concerning serum VEGF, the current results suggest a possible role for serum VEGF as an indicator of the development of HCC in patients with liver cirrhosis during follow-up and the possibility to use it as an indicator to reflect the disease's potential activity of vascular invasion and metastasis. In case of AFP, that parameter may represent a liver cellspecific marker, not a tumor-specific marker and the present results suggest to use it as a supplementary marker which may help diagnosis of HCC, but not to detect circulating HCC cells, as it was elevated in large portion of patients with localized HCC. Therefore, combination of multiple markers may be more valuable in the diagnosis and prognosis of HCC.

Moreover, it was reported that, the expression of MAGE- 1 gene, the tumor-specific marker, in HCC is more frequent than in various other cancers and several peptides of the MAGE-1 protein, which contain major histocompatibility (MHC) binding motifs and potential CTL (Cytotoxic $\mathrm{T}$ lymphocyte) epitopes were reported, so many HCC patients might be candidates for the specific immunotherapy. Furthermore, understanding of tumor angiogenesis has dramatically increased and it is hopeful that numerous drugs are currently tested and becoming available in clinic as Bevacizumab (rhuMAb-VEGF) which is a humanized murine monoclonal antibody directed against VEGF, therefore inhibiting the key factor for angiogenesis in tumors and controlling tumor growth, so it may turn it from a deadly into a chronic disease.

\section{REFERENCES}

1. Parkin, D.M.; Bray, F.; Ferlay, J. and Pisani, P. (2001): Estimating the world cancer burden: Globocan 2000. Int. J. Cancer, 94: 153-156.

2. Bruix, J.; Sherman, M.; Llovet, J.M.; Beaugrand, M.; Lencioni, R.; Burroughs, A.K.; Christensen, E; Pagliaro, L.; Colombo, $\mathrm{M}$. and Rodes, J. (2001): EASL Panel of Experts on HCC: Clinical management of hepatocellular carcinoma. Conclusions of the Barcelona2000 EASL conference. J. Hepatol., 35: 421-430.

3. Poon, R.T.; Lau, C.P.; Cheung, S.T.; Yu, W.C.; Fan, S.T. and Wong, J. (2003): Quantitative correlation of serum levels and 
tumor expression of vascular endothelial growth factor in patients with hepatocellular carcinoma. Cancer Res., 63: 3121-3126.

4. Semela, D. and Dufour, J-F. (2004): Angiogenesis and hepatocellular carcinoma. J. Hepatol., 41(5): 864-880.

5. Bosch, F.X.; Ribes, J. and Borras, J. (1999): Epidemiology of primary liver cancer. Semin. Liver Dis., 19: 271-285.

6. 6-Michielsen, P.P.; Francque, S.M. and van Dongen, J.L. (2005): Viral hepatitis and hepatocellular carcinoma. World J. Surg. Oncol., 3: 27.

7. Chevret, S.; Trinchet, J.C.; Mathieu, D.; Rached, A.A.; Beaugrand, $M$. and Chastang, C. (1999): A new prognostic classification for predicting survival in patients with hepatocellular carcinoma. J. Hepatol., 31: 133-141.

8. França, A.V.; Elias Junior, J.; Lima, B.L.; Martinelli, A.L. and Carrilho, F.J. (2004): Diagnosis, staging and treatment of hepatocellular carcinoma. Braz. J. Med. Biol. Res., 37(11) 1689-1705.

9. Mou, D.C.; Cai, S.L.; Peng, J.R.; Wang, Y.; Chen, H.S.; Pang, X.W , Leng, X.S. and Chen, W.F. (2002): Evaluation of MAGE-1 and MAGE-3 as tumor-specific markers to detect blood dissemination of HCC cells. Br. J. cancer 86(1): 110116.

10. Cai, S.L.; Chen, H.S.; Wang, Y.; Zhao, H.R.; Peng, J.R.; Pang, X.W.; Gong, S.Y.; Zhu,
J.Y.; Cong, X.; Wang, Y.; Rui, J.A.; Leng, X.S.; Du, R.Y. and Chen, W.F. (1999): Expression of MAGE-1 gene in HCC. Natl. Med. J. China 79: 668-672.

11. Xiao, J. and Chen, H-S. (2004): Biological functions of melanoma-associated antigens. World J. Gastroenterol., 10(13): 1849-1853.

12. Barker, P.A. and Salehi, A. (2002): The MAGE proteins: emerging roles in cell cycle progression, apoptosis, and neurogenetic disease. J. Neurosci. Res., 67(6): 705-712.

13. Kobayashi, Y.; Higashi, T.; Nouso, K.; Nakatsukasa, H.; Ishizaki, M.; Kaneyoshi, T.; Toshikuni, N.; Kariyama, K.; Nakayama, E and Tsuji T. (2000): Expression of MAGE, GAGE and BAGE genes in human liver diseases: utility as molecular markers for HCC. J. Hepatol., 32(4): 612-617.

14. Semenza, G.L. (2003): Angiogenesis in ischemic and neoplastic disorders. Annu. Rev. Med., 54: 17-28.

15. Kreczko, S.; Lipska A. and Wysocka J. (2000): Alphafetoprotein: diagnostic value in hepatic disorders. Pol. Merkuriusz Lek., 8(48): 420-423.

16. Wong, IH-N.; Leung, T.; Ho, S.; Lau, W.Y.; Chan, M. and Johnson, P.J. (1997): Semiquantitation of circulating hepatocellular carcinoma cells by reverse transcriptase polymerase chain reaction. Br. J. Cancer 76: 629-633.

17. Malek, L.; Jerome, N.; Herve, Z.; Abdelmajid, S.; Corinne, 
V.; Giovanna, V.; Karine, P.; Monique, T.; Frederique, C.; Stanislas, P.; Dominique, F.; Bernard, L.; Christian, B. and Paterlini, P.B. (1999): Liver resection and needle liver biopsy cause hematogenous dissemination of liver cells. Hepatology 29: 879-882.

18. Peng, J.; Cai, S.; Leng, X.; Mu, D.; Lu, J.; Chen, H. and Rui, J. (2002): mRNA of MAGE genes as specific markers in detection of tumor cells in the peripheral blood of patients with hepatocellular carcinoma. Zhonghua Yu Fang Yi Xue Za Zhi.,36(7):487-490.

19. Yang, S.Z.; Dong, J.H.; Zhu, J.; Li, K. and Zhang, Y. (2004): [Detection of AFP m-RNA and melanoma antigen-1 m-RNA in peripheral blood of patients with HCC and its clinical significance]. Zhonghua Wai Ke Za Zhi., 42(17): 1060-1063.

20. Yang, S.Z.; Dong, J.H.; Li, K.; Zhang, Y. and Zhu J. (2005): Detection of AFP mRNA and melanoma antigen gene-1 mRNA as markers of disseminated HCC cells in blood. Hepatobiliary Pancreat. Dis. Int., 4(2): 227-33.

21. Li, X.M.; Tang, Z.Y.; Qin, L.X.; Zhou, J. and Sun, H.C. (1999): Serum VEGF is a predictor of invasion and metastasis in hepatocellular carcinoma. J. Exp. Clin. Cancer Res., 18: 511-517.

22. Poon, R.T.; Ng, I.O.; Lau, C.; Zhu, L.X.; Yu, W.C. and Lo, C.M. (2001): Serum VEGF predicts venous invasion in HCC: a prospective study. Ann. Surg., 233: 227-235.

23. Li, X.; Feng, G.S.; Zheng, C.S.; Zhuo, C.K.; Chen, $K$. and Liu, X. (2004): Expression of plasma VEGF in patients with HCC and effect of transcatheter arterial chemoembolization therapy on plasma VEGF level. World J. Gastroenterol., 10(19): 28782882.

24. Schmitt, M.; Horbach, A.; Kubitz, R.; Frilling, A. and Haussinger, D. (2004): Disruption of hepatocellular tight junctions by VEGF: a novel mechanism for tumor invasion. J. hepatol., 41(2): 274-283.

25. Yao, D.F.; Wu, X.H.; Zhu, Y.; Shi, G.S.; Dong, Z.Z.; Yao, D.B.; Wu, W.; Qiu, L.W.; Meng, X.Y. (2005): Quantitative analysis of VEGF, microvascular density and their clinicopathologic features in human HCC. Hepatobiliary Pancreat. Dis. Int., 4(2): 220-226.

26. Peng, S.Y.; Chen, W.J.; Lai, P.L.; Jeng, Y.M.; Sheu, J.C. and Hsu, H.C. (2004): High AFP level correlates with high stage, early recurrence and poor prognosis of HCC: significance of hepatitis virus infection, age, p53 and beta-catenin mutations. Int. J. Cancer 112(1): 44-50.

27. Ali, M.A.; Koura, B.A.; elMashad, N. and Zaghloul, M.H. (2004): The Bcl-2 and TGF-beta1 levels in patients with chronic hepatitis C, liver cirrhosis and HCC.

Egypt.J.Immunol.,11(1):83-90.

28. He, Y.M.; Wang, X.Y.; Gao, S.D.; Yu, L.Y.; Lin, X.D. and 
Lin, L.W. (2005): Ultrasoundguided fine needle biopsy of intrahepatic nodules and low elevation of AFP in early diagnosis of hepatocellular carcinoma. Hepatobiliary Pancreat. Dis. Int., 4(1): 50-54.

29. Di Bisceglie, A.M.; Sterling, R.K.; Chung, R.T.; Everhart, J.E; Dienstag, J.L.; Bonkovsky, H.L.; Wright, E.C.; Everson, G.T.; Lindsay, K.L.; Lok, A.S.; Lee, W.M.; Morgan, T.R.; Ghany, M.G. and Gretch, D.R. (2005): Serum AFP levels in patients with advanced hepatitis C: results from the HALT-C Trial. J. Hepatol., 43(3):434-441.

30. Chu, C.W.; Hwang, S.J.; Luo, J.C.; Lai, C.R.; Tsay, S.H.; Li,
C.P.; Wu, J.C.; Chang, F.Y. and Lee,S.D.(2001):Clinical, virologic, and pathologic significance of elevated serum AFP levels in patients with chronic hepatitis C.J.Clin.Gastroenterol.,32(3):240 $-244$.

31. Jiang, S.Y.; Shyu, R.Y.; Huang, M.F.; Tang, H.S.; Young, T.H.; Roffler, S.R.; Chiou, Y.S. and Yeh, M.Y. (1997): Detection of alpha-fetoprotein expressing cells in the blood of patients with hepatoma and hepatitis. Br. J. Cancer 75: 928-933.

32. Zhou, L.; Liu, J. and Luo, F. (2006): Serum tumor markers for detection of HCC. World J. Gastroenterol., 12(8): 1175-1181. 


\section{الحامض النووي الريبوسي حامل الثفرة للجين ماج-1 ، وعامل النمو البطاني



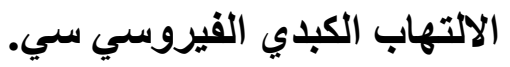

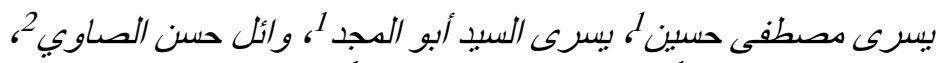

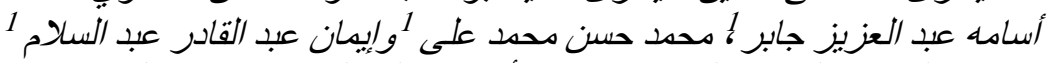

$$
\begin{aligned}
& \text { قسمي الكيمياء الحيوية الطبية وعلاج الأورام ـ كلية الطب ـ جامعة الزقازيق الطبيق }
\end{aligned}
$$

تم تقييم تعبير الحامض النووى الريبوسى حامل الثفرة للجين (ماج- ( )فى الدم و قياس



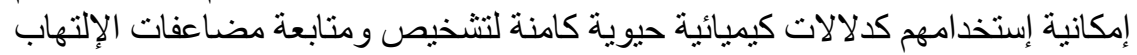

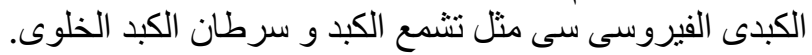

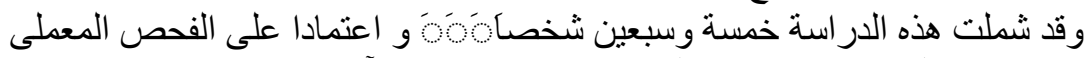

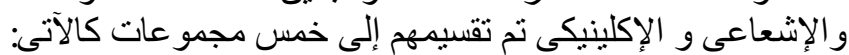

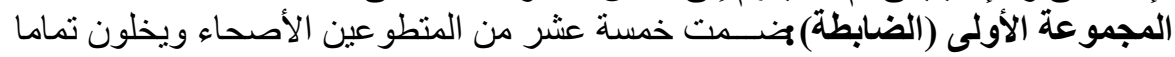



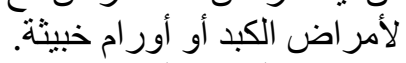
المجموعة الثانيـة: شملت 15 مريضا مصابينة بالِالإلتهاب الكبدى الفيروسى سىى.

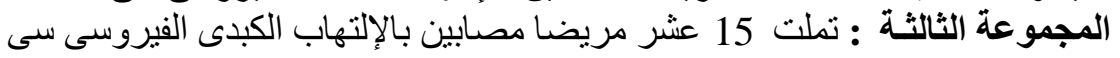
ومضاعفاته (تشمع الكبد). المجموعة الرابعة: شملت 15 مريضا مصابين بالإلتهاب الكبدى الفيروسى سى ومضاعفاته

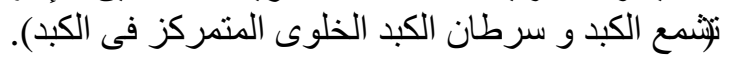



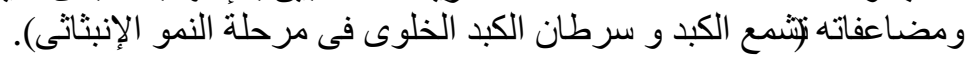



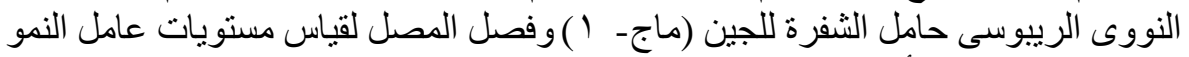

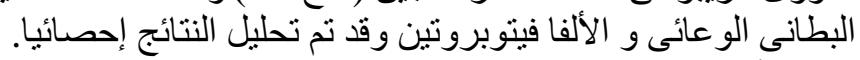

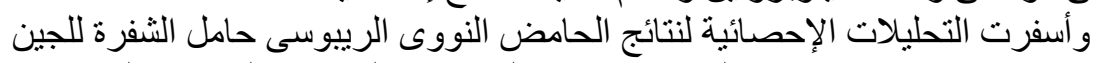

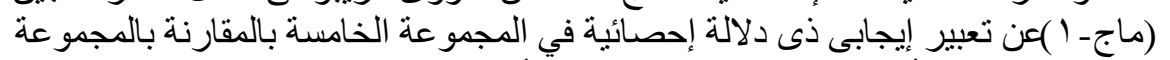



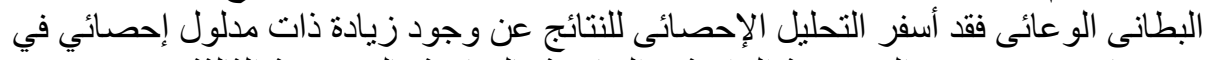

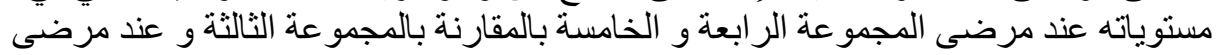

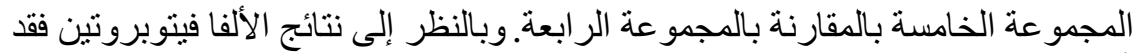

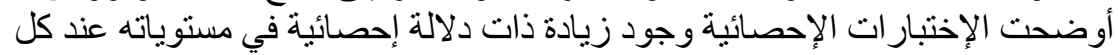

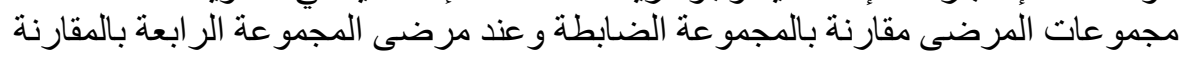

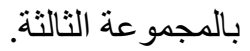




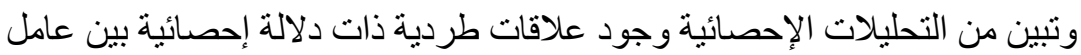

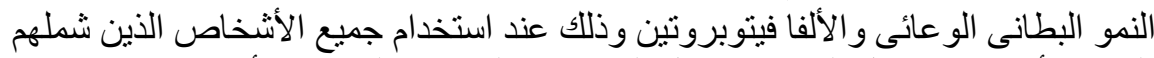

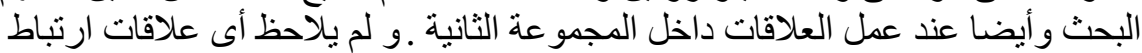

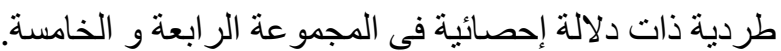

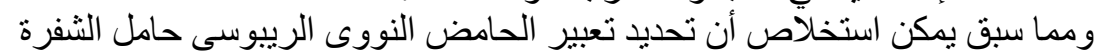

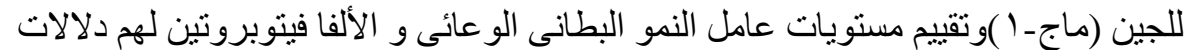

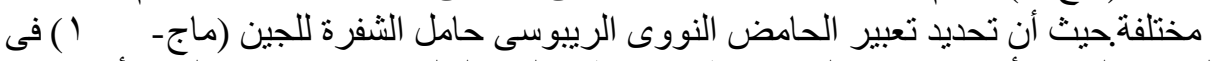

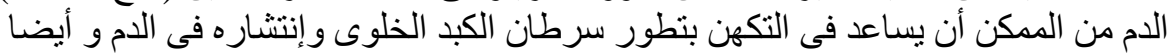

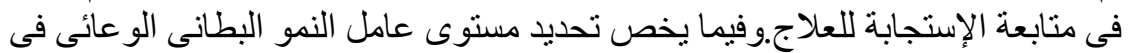





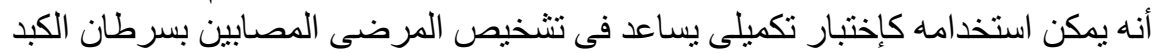

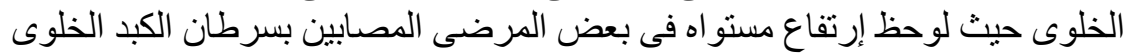

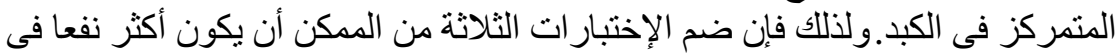



